\title{
THE ONLINE SINGLE SUBMISSION POLICY OF THE LOCAL GOVERNMENT APARATURE IN THE ERA OF GLOBALIZATION
}

\author{
Prijo Dwi Atmanto \\ Sragen Government Employees \\ prijodwiadmanto@gmail.com
}

\begin{abstract}
The Electronic Integrated Business Licensing Service, which is more easily referred to by the generic name Online Single Submission, is present in the context of business licensing services that apply in all Ministries, Institutions and Local Governments throughout Indonesia, which so far have been carried out through Pelayanan Terpadu Satu Pintu (PTSP). Apart from PTSP, the public can access the OSS System online wherever and whenever. The OSS system was built in the context of accelerating and increasing investment and business, by applying licensing to seek to be integrated electronically. In the latest regulation regarding OSS, namely Government Regulation Number 24 of 2018, the Government regulates among other things the types, applicants, and issuance of business permits; implementation of business licensing; business licensing reforms by sector, OSS system, OSS institutions, OSS funding; incentives or disincentives for business licensing through OSS; problem solving and business obstacles; and sanctions.
\end{abstract}

Keywords: Globalization, Local Government, Online Single Submission

\section{A. INTRODUCTION}

Globalization is a global economic life that is open and does not recognize territorial boundaries, or the territory between one region and another, or there are no boundaries between one country and another. This economic globalization is characterized by the existence of free trade or international trade, as a characteristic is trade and investment towards the liberalization of capitalism, so that all people are free to try anywhere and anytime in this world. ${ }^{1}$

The Act Number 23 of 2014 concerning Regional Government as

1 Ngadino, PERANAN HUKUM DALAM GLOBALISASI EKONOMI, Jurnal Pembaharuan Hukum, Volume I No.1 Januari-April 2014, P.59-65 amended several times, the latest by Law Number 9 of 2015 concerning Second Amendment to The Act Number 23 of 2014 concerning Regional Government granting authority to regions to organize regional government is directed to accelerate the realization of community welfare through improved services, empowerment, and community participation, as well as increasing regional competitiveness by taking into account the principles of democracy, governance, justice, and the uniqueness of an area in the system of the Unitary State of the Republic of Indonesia.

The efficiency and effectiveness of the administration of regional 
government need to be improved by paying more attention to aspects of the relationship between the Central Government and the regions and between regions.

In the case of licensing services, bureaucratic reform has given a real change to the community in terms of ease in the field of licensing services from year to year in the implementation of the laws and regulations in the field of licensing with the emergence of one stop service (OSS), which is a one-stop integrated service so that the community (permit applicants) does not need to bother taking care of licensing by visiting a marathon technical agency but rather through one place from registration to decision making permits. The development of this government policy progress is the impact of globalization so that it becomes the demands of the times to improve excellent service in all fields both private and public sectors.

Licensing is a form of implementing regulatory and control functions that are owned by the government of the activities carried out by the community. Licensing can take the form of registration, recommendation, certification, determination of quota, and permission to conduct a business that usually must be owned or obtained by a company or someone's organization before the person concerned can carry out an activity or action. Over time the government has issued Government Regulation Number 24 of 2018 concerning Electronic Integrated Business Licensing Services or commonly known as Online Single Submission (OSS). ${ }^{2}$

Quality of public services Quality of public services is very important. The importance of the quality of public services is a form of achievement from the government. Achievements expected by the government in public services can not be realized if there is still a lack of public services due to lack of attention from the Government / Regional Government. Public Services include three aspects, namely goods, services and administrative services. ${ }^{3}$ This is based on Law Number 25 Year 2009 regarding Public Services Article 5 which states that "The scope of public services includes public goods and public services as well as administrative services as stipulated in the legislation". One form of administrative service is the service of various licenses. Utilization of existing technological sophistication in licensing services that is provided in the form of online with the aim of users of licensing services both business entities and individuals can obtain licensing services effectively and efficiently which can ultimately reach the agreed standard of public satisfaction. ${ }^{4}$

2 Desi Arianing Arrum, Kepastian Hukum Dalam Perizinan Berusaha Terintegrasi Secara Elektronik (Online Single Submission) di Indonesia, JuristDiction: Vol. 2 No. 5, September 2019, P. 16311654.

3 Muhammad Iqbal Fitra Assegaf, Henny Juliani, Nabitatus Sa'adah, PELAKSANAAN ONLINE SINGLE SUBMISSION (OSS) DALAM RANGKA PERCEPATAN PERIZINAN BERUSAHA DI DINAS PENANAMAN MODAL DAN PELAYANAN TERPADU SATU PINTU (DPMPTSP) JAWA TENGAH, DIPONEGORO LAW JOURNAL, Volume 8, Nomor 2, Tahun 2019, P.1328-1342.

4 Anis Nur Fadhilah, Indah Prabawati, IMPLEMENTASI PELAYANAN PERIZINAN 
This is in line with Presidential Regulation No. 91 of 2017 concerning the Acceleration of Business Conduct, commonly referred to as Perpres 91/2017. Presidential Regulation $91 / 2017$ is an instrument for implementing the Economic Policy Package volume 16. This Presidential Regulation mandates the establishment of a Task Force (Task Force) at the national level, ministries / agencies, provinces, and districts / cities as well as the application of a licensing system trying to be integrated electronically (online single submission) in 2018. Until February 2018 only 10 provincial level task forces were formed and 75 district / city level task forces. On the other hand, the success of this economic package volume 16 is very much in need of the support of the regional government, especially the regional head. ${ }^{5}$

The policy is to implement the provisions of Article 25 of Law Number 25 of 2007 concerning Investment and the provisions of Article 6 and Article 7 of Law Number 23 of 2014 concerning Regional Government as amended several times, the latest by Law Number 9 of 2015 concerning Amendments Second, Act Number 23 of 2014 concerning Regional Government.

BERUSAHA TERINTEGRASI SECARA ELEKTRONIK ONLINE SINGLE SUBMISSION (OSS) STUDI PADA DINAS PENANAMAN MODAL DAN PELAYANAN TERPADU SATU PINTU (DPMPTSP) KABUPATEN NGANJUK, Publika, Vol 7, No 4 (2019).

5 Permana Sony Hendra, Peran Kepala Daerah untuk mempercepat implementasi paket kebijakan ekonomi jilid 16, Info Singkat, Bidang Ekonomi dan Kebijakan Publik, Kajian Singkat Terhadap Isu Aktual dan Strategis, vol. X, No. 03/I/Puslit/Februari/2018.
One stop service (OSS) or onestop integrated licensing service is a policy of President Joko Widodo delivered in his direction at the Merdeka Palace Jakarta on November 4, 2014 to Ministers, Governors, Regents and Mayors so that PTSP can improve the performance of its services in their respective regions each in order to attract foreign and domestic investors.

Based on the results of a survey conducted by Gajah Mada University in 2002 concerning the quality of public services after the enactment of regional autonomy in Indonesia, it is known that the efforts taken by the government have not contributed much to improving the quality of public services. Even the public service bureaucracy is still unable to provide pub lic services as expected by the community. It is different from a number of regions which are the opposite. Public services in the field of licensing carried out in Sragen Regency, Central Java Province, Jembrana Regency, Bali Province, Solok Regency, West Sumatra Province, and Pare-Pare City, South Sulawesi Province are considered successful in fulfilling their duties. ${ }^{6}$

The implementation of regional autonomy in Indonesia began on January 1,2001 . In the era of regional autonomy, in accordance with the mandate of Law Number 22 of 1999 which was later amended by Law Number 32 of 2004 and amended by Law Number 23 of 2014 concerning Regional Governments, Regency / City

6 Agus Dwiyanto dalam Winata, Kinerja Unggul DPMPTSP Sragen, LP3AN Universitas Padjadjaran, Cetakan Pertama: Januari 2018 Bandung, P.1 
Governments have the authority to regulate and manage their own households in order to improve welfare and bring public services closer to the community. The granting of this authority is based more on the demand of public accountability, namely the responsibility of the regency / city government towards the community that should be served. The actual manifestation and commitment of public accountability is only shown in the form of performance, including the quality of service performance of institutions and government officials.

Regional autonomy aims to bring closer and provide quality public services. The quality of service provided by district/city government officials to the community is an indicator of the success of regional autonomy. The services provided are not only fast, but also appropriate to the needs and expectations of the local community.

The reality on the ground is that the performance of the government in the field of public services is still not optimal including the non-optimal performance of the service bureaucracy in the field of licensing and nonlicensing with a one-stop integrated service approach (PTSP) or One Stop Service (OSS) in 2002 in which the Regency / City is the center PTSP implementation.

Based on Keputusan Menteri
Pendayagunaan Aparatur Negara
(Menpan) Nomor 63Tahun 2003 tentan
g Pedoman UmumPenyelenggaraan
Pelayanan Publik, the types of public
services are divided into 3 groups,
namely:

1. Administrative service groups, namely services that produce various forms of official documents needed by the public such as citizenship status, certificates of competency ownership or control of an item and so on. Documents produced from this type of service include: Resident Identity Card (KTP), civil registration deeds, proof of ownership of motorized vehicles (BPKB), Driving License (SIM), Building Permit, and others.

2. Goods service group is a service that produces various forms or types of goods used by the public, for example telephone networks, electricity supply, drinking water and so on.

3. Service groups are services that produce forms of services needed by the public such as education, maintenance, health, transportation, telecommunications and so on.

The ease of licensing services was followed up with the issuance of Government Regulation Number 24 of 2018 concerning Electronic Business Licensing Services Licensing.

The OSS system is a system that integrates all business licensing services that are the authority of Ministers / Institutional Leaders, Governors or Regents / Mayors conducted through electronic. This is stated in Article 1 number 5 of Government Regulation Number 24 Year 2018 regarding Electronic Integrated Business Licensing Services that business licensing is electrically or Online Single Submission, hereinafter abbreviated as OSS, is a business license issued by OSS institutions for 
and on behalf of the Minister, the head of an institution , governor, or regent / mayor to business people through an integrated electronic system.

\section{B. DISCUSSION}

\section{ONLINE POLICY ON SINGLE SUBMISSION IN ACCELERATION OF BUSINESS IMPLEMENTATION}

The issuance of economic policy packages in the era of President Joko Widodo's administration, specifically in the area of licensing, namely the Economic Policy Package volume 16 , as outlined in Presidential Regulation No. 19 of 2017 concerning Acceleration of Business Implementation is expected to provide facilities for investment.

Businesspeople's complaints that assume that long and complicated licensing and bureaucracy that does not reflect good governance should be ignored by the release of the economic policy package Chapter 16.

This policy breakthrough can increase investor confidence in investing. Based on data from the ministry after the issuance of Presidential Regulation No. 91 of 2017 concerning the Acceleration of Business Implementation, from US $\$ 34.5$ billion to US $\$ 42.6$ billion in 2017. The largest investment is in the manufacturing sector with a value of US \$ 21.6 billion with 256 projects, followed by the tourism sector with a value of US \$17 billion with 159 projects, and the public works and public housing sector with a value of US $\$ 1.2$ billion with 98 projects. ${ }^{7}$

In the area of licensing, the implementation of the economic policy package volume 16 is followed up with the issuance of Government Regulation Number 24 of 2018 concerning Electronic Business Licensing Services. This provision is a follow up to the existence of the one stop service system (OSS) and Presidential Regulation Number 19 of 2017 concerning Acceleration of Business Implementation. One stop service is a one-stop licensing service to simplify the bureaucratic process in the field of licensing in one place.

The policy is very beneficial for business actors because it can cut bureaucracy so that it does not seem convoluted or effective and efficient. Business operators do not need to take care of licensing in a partial but comprehensive and easy manner in one place, namely the Licensing Services Office or the One-Stop Integrated Licensing Services Agency.

But whether in its implementation all institutions/agencies/ ministries or regional governments have implemented it properly and correctly and consistently, this is proven by the practice in the Online Single Submission service. Observations in the field show that the implementation of Online Single Submission between ministries is still not optimal because there are still sectoral regulations that are 
technical in nature according to the type of licensing.

The way to access the Online Single Submission (OSS) system is actually quite easy. Investors or business actors can simply bring the company deed of establishment from a notary that has been ratified to Pelayanan Terpadu Satu Pintu (PTSP) in Badan Koordinasi Penanaman Modal (BKPM) of the relevant ministries / institutions that already has a Pelayanan Terpadu Satu Pintu (PTSP).

After the data is entered, the system will automatically confirm the data. The system is connected to the database of the Directorate General of General Law Administration for endorsement of business entities. If in the form of an individual business entity, the system will be integrated with the NIK and confirm the identity of the applicant and the Taxpayer Identification Number (NPWP). After that, the Business Entity Number (NIB) will appear. BPJS employment and health, location permits, fiscal facilities, and Foreign Worker Use Plans (RPTKA) that are already available in the cloud data so that they do not need to be inputted again. ${ }^{8}$

Then the registration stage is complete, the system will ask investors for commitment. The commitment in question is:

a. Includes environmental permits, Environmental Management

8 https://dunianotaris.com/online-singlesubmission-oss-perizinan-usaha-lebih-cepat.php, juni 2018.
Efforts and Environmental Monitoring Efforts (UKL-UPL) which must be completed within 12 days.

b. Compliance with Building Permit (IMB) standards within 30 days.

c. Compliance with the Certificate of Eligibility Functions standard must be fulfilled within 3 days.

As a policy, if permits have not been fulfilled, they can be taken care of offline. If all commitments are fulfilled, a sectoral business permit and a Trade Business License (SIUP) will automatically be issued. Then after obtaining the permit, there are more commitments that must be fulfilled namely:

a. Mandatory Indonesian National Standards and voluntary Indonesian National Standards that must be fulfilled within 14 days.

b. If investment in the pharmaceutical and health sector, then there needs to be a way of making good medicines and ways of making good traditional medicines which are administered for 35 days and how to make good medical devices with a period of 5 days.

If all of the above commitments are fulfilled, a commercial or operational permit will be issued in the form of a marketing authorization and certification.

Until January 2018 a single online submission system has not yet been published, there are still 
improvements or improvements to the system that have been made. Difficult to realize investment because of the still difficult bureaucracy faced by investors in the field, which makes the ecosystem try in Indonesia. ${ }^{9}$

Pelayanan Terpadu Satu Pintu (PTSP), which is now not optimal, because it still has to face PTSP from other Ministries, so investors still have to go to several tables, this has become out of sync.

Implementation of Online Single Submission (OSS) can reduce the costs incurred by investors in administrative matters. If the arrangement is done online, it can reduce intermediaries. This means that this system can reduce licensing costs that must be borne by business actors or investors, thus achieving the goal to accelerate the implementation of business. ${ }^{10}$

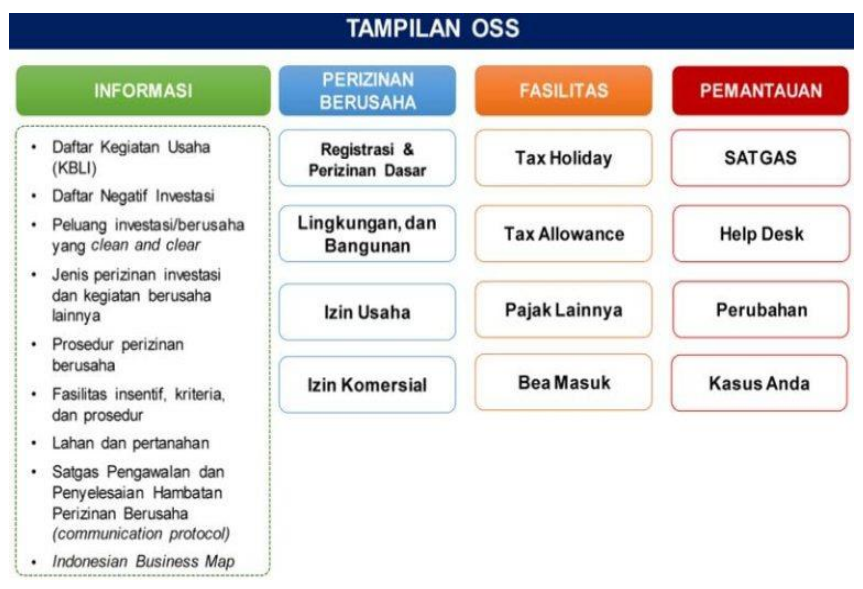

\section{REGIONAL GOVERNMENT APARATIC READINESS}

The idea of cheap, easy, fast, and transparent licensing became the ideals of President Joko
Widodo's Government. This idea was manifested in a policy with the issuance of Government Regulation Number 24 of 2018 concerning Electronic Integrated Business Licensing Services, which is usually called the Online Single Submission (OSS).

This policy is an implementation of the economic package Volume 16 and the follow up of Presidential Regulation No. 91 of 2017 concerning the Acceleration of Business Conduct.

With the enactment of Law Number 23 Year 2014, local governments play a role in the implementation of licensing and non-licensing in the regions to increase investment so that it can increase local revenue and improve the welfare of the community by providing facilities to investors / business actors.

But with the Online Single Submission (OSS) system, licensing must be done through an internet application online and nationally integrated at the central level and then only follows up both those with commitments and without commitments to take care of the required permits in accordance with statutory regulations laws that apply.

However, the implementation of licensing services in the regions still cannot be carried out in accordance with the provisions because there are several factors including infrastructure that is not optimally available evenly in all regions and also human resource factors that understand information 
technology and especially the mentality of the officers / officials who handle licensing is still think less reformative and still think partial / sectoral and not yet comprehensive.

Just as some regions have not been able to implement a single online submission. Although the government has officially launched the online single submission integrated licensing system on Monday, July 9, 2018, according to the Special Staff of the Coordinating Minister for the Economy Edy Putra Irawady, there are still many regions that have not been able to implement the service. One of the obstacles faced by local governments is infrastructure, there are still areas where IT systems and bandwidth are still weak so that one-stop integrated services cannot enter. ${ }^{11}$

Another obstacle is the field of human resources, because not all regions ready for this system have competent human resources. The government hopes and targets the implementation of online single submission no later than 2019.

Judging from Friedmann's theory, the law can work if the three components can run well. From the structure, the readiness of human resources is not yet optimal. It is evident that there are still many regions that are not ready with the online single Submision. Whereas for the substance of the integrated licensing service rules already exist namely the
Presidential Regulation Number 91 of 2017 concerning the Acceleration of Business Implementation, and Government Regulation Number 24 of 2018. However, when seen from the general provisions of Article 1 number 11 of Government Regulation Number 24 of 2018, it states that the institution manager and organizer of OSS is a nonministerial government institution that organizes government affairs in the field of investment coordination. Even though in Law Number 25 Year 2007 it is explained that the body that handles investment is BKPM. If this Government Regulation Number 24 of 2018 is enforced, all the licensing tasks will be taken over by the new OSS institution. Meanwhile, when viewed from the order of the laws and regulations, the Government Regulation is lower than the Law whose nomenclature is clearer.12 I

The Electronic Integrated Business Licensing Service, which is more easily referred to by the generic name Online Single Submission, is present in the context of business licensing services that apply in all Ministries, Institutions and Local Governments throughout Indonesia, which so far have been carried out through Pelayanan Terpadu Satu Pintu (PTSP). Apart from PTSP, the public can access the OSS System online wherever and whenever.

The OSS system was built in the context of accelerating and 
increasing investment and business, by applying licensing to seek to be integrated electronically. In the latest regulation regarding OSS, namely Government Regulation Number 24 of 2018, the Government regulates among other things the types, applicants, and issuance of business permits; implementation of business licensing; business licensing reforms by sector, OSS system, OSS institutions, OSS funding; incentives or disincentives for business licensing through OSS; problem solving and business obstacles; and sanctions.

The difference between Online Single Submission and licensing before OSS is that the OSS system reverses the previous licensing process. If previously an operational permit or commercial permit was issued after a series of licenses such as environmental permit, AMDAL, etc. were pocketed by the entrepreneur. But with OSS, with a Business Identification Number (NIB), entrepreneurs can get operational and commercial licenses, and the AMDAL process is completed in stages after the NIB is published.

Nevertheless, the AMDAL process that was put in place after the NIB was published received the attention of several parties such as academics and environmental activists. Environmental expert Hariadi Kartodiharjo highlighted Government Regulation Number 24 Year 2018 regarding Electronic Integrated Business Licensing Services which laid down the mandatory AMDAL after the issuance of NIB, this action actually weakened the position of the AMDAL which had been functioning as a decision maker. Hariadi also emphasized that the Government Regulation on OSS is contrary to the spirit of Law Number 32 of 2009 concerning Environmental Protection and Management (PPLH) which strengthens the position of the AMDAL. ${ }^{13}$

So the environmental consideration should not only be to maintain the project and then the impacts will be handled, but instead the position of the AMDAL can come to a decision that the project cannot be carried out. Government Regulation Number 24 Year 2018 regarding Electronic Integrated Business Licensing Services itself has weakened the position of AMDAL even though in Law Number 32 Year 2009 Environmental Protection and Management appear other things such as Strategic Environmental Assessment (KLHS), and several environmental instruments whose purpose at the time of manufacture was to realize that the AMDAL was weak, so that it was added by several other instruments. ${ }^{14}$

There is a concept that is not appropriate in the issuance of OSS, matters of acceleration of permits do not necessarily be measured by shortened time. The main problem

13 Ibid.

14 downloaded from: Hariadi dalam hukum online https://www.hukumonline.com/berita/baca/lt5cdc 18e537f3c/pp-oss-dinilai-lemahkan-posisi-wajibamdal. 
related to licensing in Indonesia is a conflict of interest that causes corruption, bribery and others. This means that licensing issues are on the governance side and not the simplification of procedures. The government should prioritize disclosure of public information related to $A M D A L$, or strengthen the AMDAL assessment team which is not addressed in the provisions of Government Regulation Number 24 Year 2018 regarding Electronic Integrated Business Licensing Services (OSS). The presence of Government Regulation Number 24 Year 2018 regarding Electronic Integrated Business Licensing Services actually makes the AMDAL position not strategic when only by pocketing a commitment permit, business actors can get an environmental permit. And with the environmental permit capital, business actors can carry out various activities such as land acquisition and so on. So that the existence of an AMDAL does not affect anything on the project except mitigation related impacts that must be addressed.

While the legal culture of the community in terms of online licensing single Submision. not all can do it because of the limited ability of human resources to information technology systems. Not all plural societies with varying levels of education all understand an increasingly sophisticated information technology transfer. The traditional culture in managing licenses that depend on service officers makes the attitude of behavior that is completely manual and when the licensing system is changed with the online system, many people / business actors have not been able to use / utilize the system so that there is a need for socialization which takes significant time.

Besides that, with the Government Regulation Number 24 Year 2018 regarding Electronic Integrated Business Licensing Services, the role of affected communities becomes narrower and even the role of civil society is increasingly lost because in the Regulation involved are affected communities, while other communities such as environmentalists Other NGOs did not have a place for monitoring

\section{CONCLUSION}

The licensing service policy seeks to be integrated electronically or the so-called online single submission set forth in Government Regulation Number 24 of 2018 and other provisions namely Presidential Regulation No. 91 of 2017 concerning the Acceleration of Business Conduct, along with the economic policy package volume 16 aims to be good for the sake of ease of investment, but there are still many obstacles faced by officers/ officials and business actors, namely infrastructure, and human resources. From the institutional point of view, OSS is in conflict with Law Number 25 on Investment because the body that should manage investment is BKPM. 


\section{BIBLIOGRAPHY}

Agus Dwiyanto dalam Winata, 2018, Kinerja Unggul DPMPTSP Sragen, LP3AN Universitas Padjadjaran, Bandung;

Anis Nur Fadhilah, Indah Prabawati, IMPLEMENTASI PELAYANAN PERIZINAN BERUSAHA TERINTEGRASI SECARA ELEKTRONIK ONLINE SINGLE SUBMISSION (OSS) STUDI PADA DINAS PENANAMAN MODAL DAN PELAYANAN TERPADU SATU PINTU (DPMPTSP) KABUPATEN NGANJUK, Publika, Vol 7, No 4 (2019);

Desi Arianing Arrum, Kepastian Hukum Dalam Perizinan Berusaha Terintegrasi Secara Elektronik (Online Single Submission) di Indonesia, Jurist-Diction, Vol. 2 No. 5, September 2019;

Muhammad Iqbal Fitra Assegaf, Henny Juliani, Nabitatus Sa'adah, PELAKSANAAN ONLINE SINGLE SUBMISSION (OSS) DALAM RANGKA PERCEPATAN PERIZINAN BERUSAHA DI DINAS PENANAMAN MODAL DAN PELAYANAN TERPADU SATU PINTU (DPMPTSP) JAWA TENGAH, DIPONEGORO LAW JOURNAL, Volume 8, Nomor 2, Tahun 2019;

Ngadino, PERANAN HUKUM DALAM GLOBALISASI EKONOMI, Jurnal Pembaharuan Hukum, Volume I No.1 Januari-April 2014;

Permana Sony Hendra, Peran Kepala Daerah untuk mempercepat implementasi paket kebijakan ekonomi jilid 16, Info Singkat, Bidang Ekonomi dan Kebijakan Publik, Kajian Singkat Terhadap Isu Aktual dan Strategis, vol. $X$, No. 03/I/Puslit/Februari/2018;

https://www.hukumonline.com/berita/baca/lt5cdc18e537f3c/pp-oss-dinilai-lemahkan-posisiwajib-amdal.

www.Kliklegal.com 